\title{
Influence of Fertigation Doses and Mulching on Yield Attributing Characters and Post-Harvest Shelf Life of Pointed Gourd (Trichosanthes dioica Roxb.)
}

\author{
H. Nayak ${ }^{1}$, D. Sahoo ${ }^{1 *}$, S.C. Swain ${ }^{2}$, B. Jena ${ }^{3}$, D. Paramjita ${ }^{4}$ and B.S. Bisoyi ${ }^{5}$ \\ ${ }^{1}$ Department of Vegetable Science, College of Agriculture, Orissa University of Agriculture \\ and Technology-751003, India \\ ${ }^{2}$ Precision Farming Development Centre, Orissa University of Agriculture and \\ Technology-751003, India \\ ${ }^{3}$ Department of Agriculture Chemistry and Soil Science, Orissa University of Agriculture and \\ Technology-751003, India \\ ${ }^{4}$ SMS (Soil and Water Conservation Engineering) KVK Jagatsinghpur, India \\ ${ }^{5}$ Department of Agronomy, College of Agriculture, Chiplima, India \\ *Corresponding author
}

\begin{tabular}{|l|}
\hline Key w o r d s \\
Pointed Gourd, \\
$\begin{array}{l}\text { Fertigation, } \\
\text { Mulching, Shelf life }\end{array}$ \\
\hline Article Info \\
\hline $\begin{array}{l}\text { Accepted: } \\
\text { 26 March } 2018 \\
\text { Available Online: } \\
\text { 10 April 2018 }\end{array}$ \\
\hline
\end{tabular}

A B S T R A C T

Pointed gourd (Trichosanthes dioica Roxb.) is a tropical perennial cucurbitaceous vegetable crop, commonly called as 'Parval'. It has very high nutrient content as compared to other cucurbits. Protein content of pointed gourd is 10 times that of bottle gourd and 4 times that of snake gourd, ridge gourd and wax gourd. Pointed Gourd is cultivated in spring-summer and rainy season in Odisha's weather condition but gives higher yield in spring-summer season. As most of the fruiting season falls under water scarcity period i.e., spring-summer judicious irrigation along with fertiliser application and mulching plays an important role in its yield attributing characters as well as post-harvest self-life. Hence, a field experiment was conducted to study the influence of fertigation doses and mulching on yield attributing characters and post-harvest shelf life of pointed gourd cultivation in red lateritic soils of Odisha. In the present study it is seen that application of different graded doses of $\mathrm{N}, \mathrm{P}$ and $\mathrm{K}$ through fertigation in association with mulching increased the yield attributing characters and shelf life of pointed gourd. The results revealed that the maximum values for the yield attributing traits such as length of fruit $(9.09 \mathrm{~cm})$, single fruit weight $(26.13 \mathrm{~g})$, minimum number of days taken for $50 \%$ flowering (66.34) and post- harvest parameters such as duration of maximum retention of shelf life (15.2), percentage of marketable fruits (83.54) was recorded with the application of 100 percent $\mathrm{N}, \mathrm{P}$ and $\mathrm{K}$ (RDF) through fertigation and mulching which remained at par with treatment where 80 percent $\mathrm{N}, \mathrm{P}$ and $\mathrm{K}$ is applied through fertigation and mulching. Thus, $80 \%$ fertigation with mulch was the most effective treatment with $20 \%$ fertiliser saving and duration of retention of shelf life of fruit was extended 5.6 days more as compared to the control. Plastic mulch has been used in some treatments to warm the soil, conserve the moisture, control weed population, reduce leaching of nutrients, provide protection against soil pathogens and helped in increasing duration of maximum retention of self-life, percentage of marketable fruits and thus post-harvest shelf life of fruit. 


\section{Introduction}

Pointed gourd (Trichosanthes dioica Roxb.) is an important remunerative perennial cucurbitaceous vegetable crop of Odisha and is known as the king of gourds because of very high nutrient content as compared to other cucurbits. Protein, mineral, fibre and calcium content of pointed gourd leaves is highest $(5.4 \mathrm{~g}, 3.0 \mathrm{~g}, 4.2 \mathrm{~g}$ and $531 \mathrm{mg}$ per 100 $\mathrm{g}$ of edible portion, respectively) among all the cucurbits and it also provides high energy of about 55 kilocalories.

Parval is an intensively cultivated cucurbitaceous vegetable in the eastern part of India, particularly in Odisha, Bengal, Assam, Bihar and some parts of Madhya Pradesh, Gujarat, and eastern Uttar Pradesh. It is also grown in a limited scale in hilly tracts of south Indian states like Andhra Pradesh, Tamil Nadu and Karnataka. In Bihar and eastern UP pointed gourd is grown in diara lands near the rivers. It is a semi perennial creeper, remaining dormant during winter season and again sprouts come from the underground tuberous roots with the onset of springsummer season. Its immature and tender fruits are available for 8-10 months from FebruaryMarch to October-November excepting few winter months but under protected condition it is cultivated round the year. It is seen that most of the fruiting season falls under water scarcity period i.e. spring-summer so proper care should be taken during summer months towards judicious irrigation, fertilizer application and mulching. Since it is a heavy feeder and responds well to fertilisers suitable doses of fertilisers under advanced agrotechniques like drip and mulching are essential.

Fertiliser application with drip irrigation allows application of nutrients exactly and uniformly only to the wetted root zone, where the active roots are concentrated and provides an excellent opportunity to maximize yield and minimize environmental pollution (Hagin et al., 2002). This remarkably increases the efficiency of the fertilizer as a result reducing the amount of applied fertilizer and maintains the soil health. Fertigation not only reduces the production cost by using less fertilisers but also lessens the potential of groundwater pollution caused by fertilizer leaching. It allows adjustment of the amount and concentration of the applied nutrients to meet the actual nutritional requirement of the crop throughout the growing season and provides the best way to apply fertilizers physically to the crop root zone that ensures higher and quality yield along with saving of time, labour and reducing potential pollution hazard The use of plastic mulch on raised beds in drip irrigation is now common in horticultural crop production that serves to retain injected fumigants and nutrients, maintains bed shape and keeps the lower fruit away from the soil.

However, no work has been carried out on effect of fertigation and plastic mulching on growth and yield of pointed gourd in lateritic soils of Odisha. Therefore, the present investigation has been carried out to study the influence of fertigation and mulching on yield attributing characteristics and post-harvest shelf life of pointed gourd that makes it marketable.

\section{Materials and Methods}

The present investigation entitled "Influence of fertigation doses and mulching on yield attributing characters and post-harvest shelf life of pointed gourd (Trichosanthes dioica Roxb.)" was carried out during 2016-17 at the experimental field of Precision Farming Development Centre, Horticulture Research Station (HRS), Orissa University of Agriculture and Technology (OUAT), Bhubaneswar. The Horticulture Research Station is about $5 \mathrm{~km}$ away from OUAT 
campus, Bhubaneswar situated at an latitude of $20^{\circ} 15^{\prime} \mathrm{N}$ and longitude of $85^{\circ} 52^{\prime} \mathrm{E}$, with an altitude of $25.5 \mathrm{~m}$ above MSL and about 40 $\mathrm{km}$ away from Bay of Bengal. The recommended dose of pointed gourd was 150:60:80 kg N: P: K/ha. The experiment was conducted with eight treatments including control. Different treatments were taken including fertigation with recommended dose of fertilizer and mulching.

\section{Details of treatments}

$\mathrm{T}_{1}$ : Fertigation with $100 \% \mathrm{RDF}$

$\mathrm{T}_{2}$ : Fertigation with $80 \% \mathrm{RDF}$

$\mathrm{T}_{3}$ : Fertigation with $60 \% \mathrm{RDF}$

$\mathrm{T}_{4}$ : Fertigation with $100 \% \mathrm{RDF}+$ mulching

$\mathrm{T}_{5}$ : Fertigation with $80 \% \mathrm{RDF}+$ mulching

$\mathrm{T}_{6}$ : Fertigation with $60 \% \mathrm{RDF}+$ mulching

$\mathrm{T}_{7}$ : Drip irrigation $+\mathrm{RDF}$ in soil application

$\mathrm{T}_{8}$ : Irrigation in furrow without mulching + RDF in soil application

The experiment was laid out as per Randomized Complete Block Design (R.C.B.D.) consisting of eight treatments with three replications. The experimental area was divided into 24 plots of $5 \mathrm{~m} \times 4 \mathrm{~m}$ and each plot consisted of 25 plants planted at a spacing of $1.2 \mathrm{~m} \times 1 \mathrm{~m}$. The individual plots were incorporated with organic manures such as FYM@ 5 t/ha 15 days before transplanting and were allowed for decomposition. After incorporation of organic manures, the plots were levelled properly. The plots were planted with rooted cuttings of pointed gourd both male and female plants in 1:10 ratio at a spacing of $1.2 \mathrm{~m} \times 1 \mathrm{~m}$ accommodating 25 plants per plot. Light irrigation was given by rose cane after planting for easy establishment. Subsequent irrigation was continued through drip irrigation throughout the cropping period. The recommended fertilizer dose of 150:60:80 kg/ha with respect to $\mathrm{N}, \mathrm{P}_{2} \mathrm{O}_{5}$ and $\mathrm{K}_{2} \mathrm{O}$ were applied in split doses during the entire cropping period. $\mathrm{N}$, $\mathrm{P}_{2} \mathrm{O}_{5}$ and $\mathrm{K}_{2} \mathrm{O}$ were applied through Urea (46:0:0), IFFCO (18:18:18) and SOP (0:0:50) with drip irrigation at one month interval throughout the cropping period.

Harvesting of fruits started after 95 days of transplanting which continued for about eight months. Biometric observations viz., yield and yield attributing parameters (number of days taken for $50 \%$ flowering, fruit length, fruit girth, average single fruit weight, number of seeds per fruit) and post-harvest parameters (duration of maximum retention of shelf life and percentage of marketable fruits) were recorded. The collected data were subjected to statistical analysis as per Sukhatme and Amble (1995).

\section{Results and Discussion}

\section{Yield attributing characters}

Application of 100 percent RDF through fertigation and mulching $\left(\mathrm{T}_{4}\right)$ significantly reduced the number of days taken for 50\% flowering than other treatments including control but remained at par with treatment where 80 percent RDF is applied through fertigation and mulching. The results indicated that the minimum number of days taken for $50 \%$ flowering was 66.34 days (Table 1).

It was also revealed that the individual fruit length was significantly superior in $T_{4} \quad(9.09$ $\mathrm{cm})$ than all other treatments observed in the trials except $\left(\mathrm{T}_{5} \quad 8.52 \mathrm{~cm}\right) . \mathrm{T}_{4}(9.09 \mathrm{~cm})$ and $\mathrm{T}_{5}(8.52 \mathrm{~cm})$ treatments were at par with each other. The fruit length was lowest in $\mathrm{T}_{8}$ (5.46 $\mathrm{cm}$ ) which was the control (Table 1). As 
regards to the fruit girth is concerned no significant difference has been observed among treatments the fruit girth ranged between $6.74 \mathrm{~cm}$ to $9.23 \mathrm{~cm}$.

The single fruit weight ( $26.13 \mathrm{~g})$ was found to be significant with reference to application of 100 percent $\mathrm{N}, \mathrm{P}$ and $\mathrm{K}$ (RDF) through fertigation and mulching $\left(\mathrm{T}_{4}\right)$ over other treatments but remained at par with treatment where 80 percent RDF was applied through fertigation and mulching (Table 1).

The data recorded on number of seeds per fruit of pointed gourd revealed that there was no significant variation in the number of seeds per fruit of pointed. However, number of seeds per fruit ranged between 11.6 and 14.68.

\section{Post-harvest parameters}

From the Table 1 it was clear that duration of maximum retention of shelf life was highest with $\mathrm{T}_{4}$ (15.2) followed by $\mathrm{T}_{5}$ (13.4) which were significantly different from all other treatments. Minimum duration of retention of shelf life was recorded with $\mathrm{T}_{8}$ (7.8) which happens to be in the control. It was also seen that the percentage of marketable fruits was significantly influenced by different treatments.

The maximum percentage of marketable fruits was found to be in $\mathrm{T}_{4}(83.54 \%)$ followed by $\mathrm{T}_{5}(80.95 \%) . \mathrm{T}_{4}(83.54 \%)$ and $\mathrm{T}_{5}(80.95 \%)$ were significantly superior to all other treatments and remained at par with each other. Minimum percentage of marketable fruits was recorded with $\mathrm{T}_{8}(63.57 \%)$.

\section{Yield attributing characters}

It is observed that fertigation and mulching might have helped to absorb more nutrients which was utilized for initiation of the flowering bud and ultimately develop the flower within a shortest possible period thus treatments where 80 percent RDF was applied through fertigation and mulching resulted in early production of $50 \%$ flowers which resulted in early production of fruits (Fig. 1). Use of mulch and optimum nutrient application through drip resulted in enhanced source capacity and sink strength due to continuous nutrient availability with favourable moisture regime, which in turn might have influenced yield attributing characters like days to $50 \%$ flowering, number of fruits and fruit length. These findings are confirmation with the reports Choudhari and More (2002) in cucumber.

The increase in fruit length might be due to increased fertilizer and water use efficiency. Rani et al., (2012) in pointed gourd noted the maximum fruit length of $10.55 \mathrm{~cm}$ with $100 \%$ fertigation + mulch.

As regards to the single fruit weight is concerned the treatment where 80 percent RDF was applied through fertigation and mulching resulted in production of more amounts of food materials and accumulation of the same in the fruit, thereby increasing the individual fruit weight (Fig. 2)

The results are in confirmation with the findings of Taiz and Zeiger (1991). They reported that phosphorus hastens plant energy metabolism and increases cell division, cell enlargement and ultimately yield. Grubben (1997) reported that the improved supply of plant nutrients by application of fertilizer would led to better utilization of carbon and subsequent synthesis of assimilates. These assimilates produced during photosynthesis were translocated to the various sinks which resulted in increased single fruit weight. Rani et al., (2012) in pointed gourd recorded highest fruit weight $(38.50 \mathrm{~g} /$ fruit $)$ and average fruit weight per vine $(6.31 \mathrm{~kg})$ with $100 \%$ fertigation + mulch. 
Fig.1 Effect of graded doses of fertigation and mulching on number of days to $50 \%$ flowering of pointed gourd

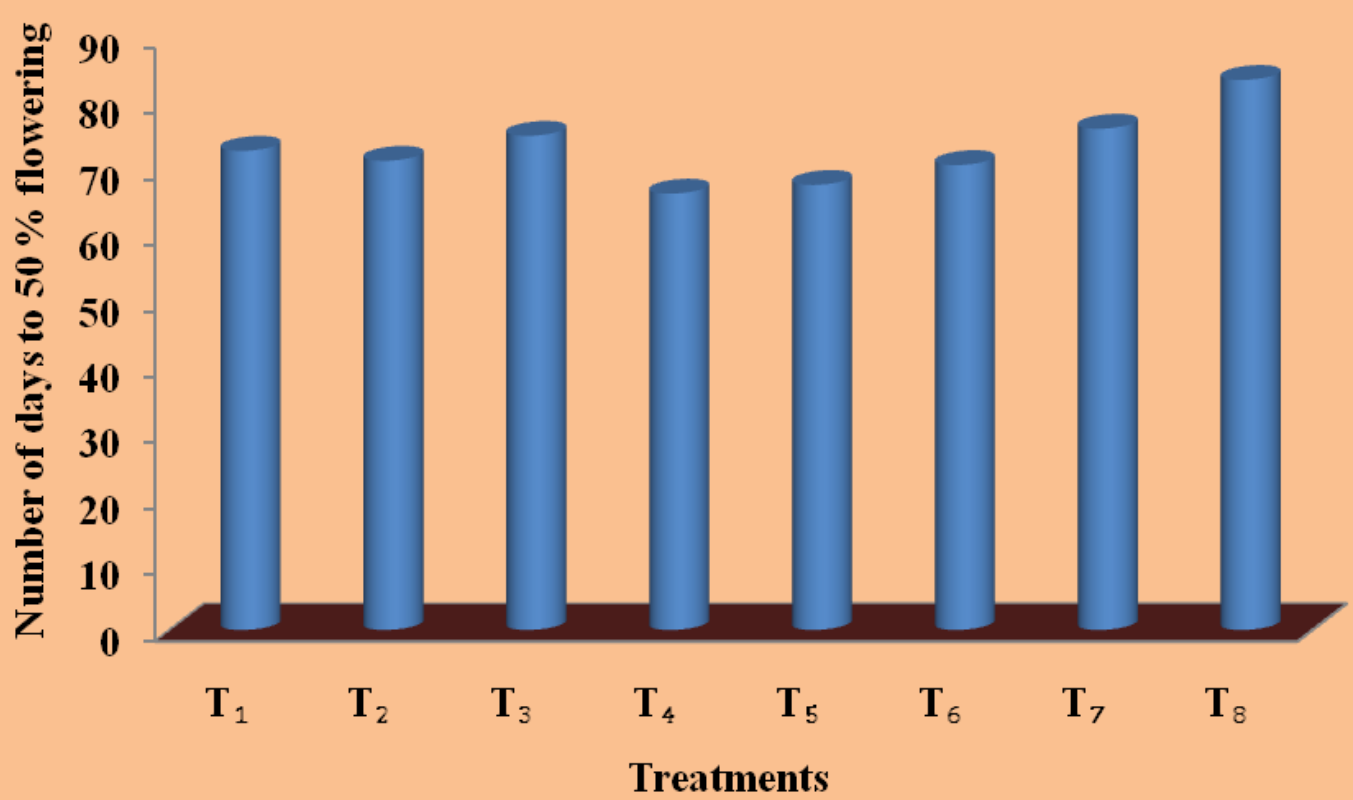

Fig.2 Effect of graded doses of fertigation and mulching on single fruit weight (gm) of pointed gourd

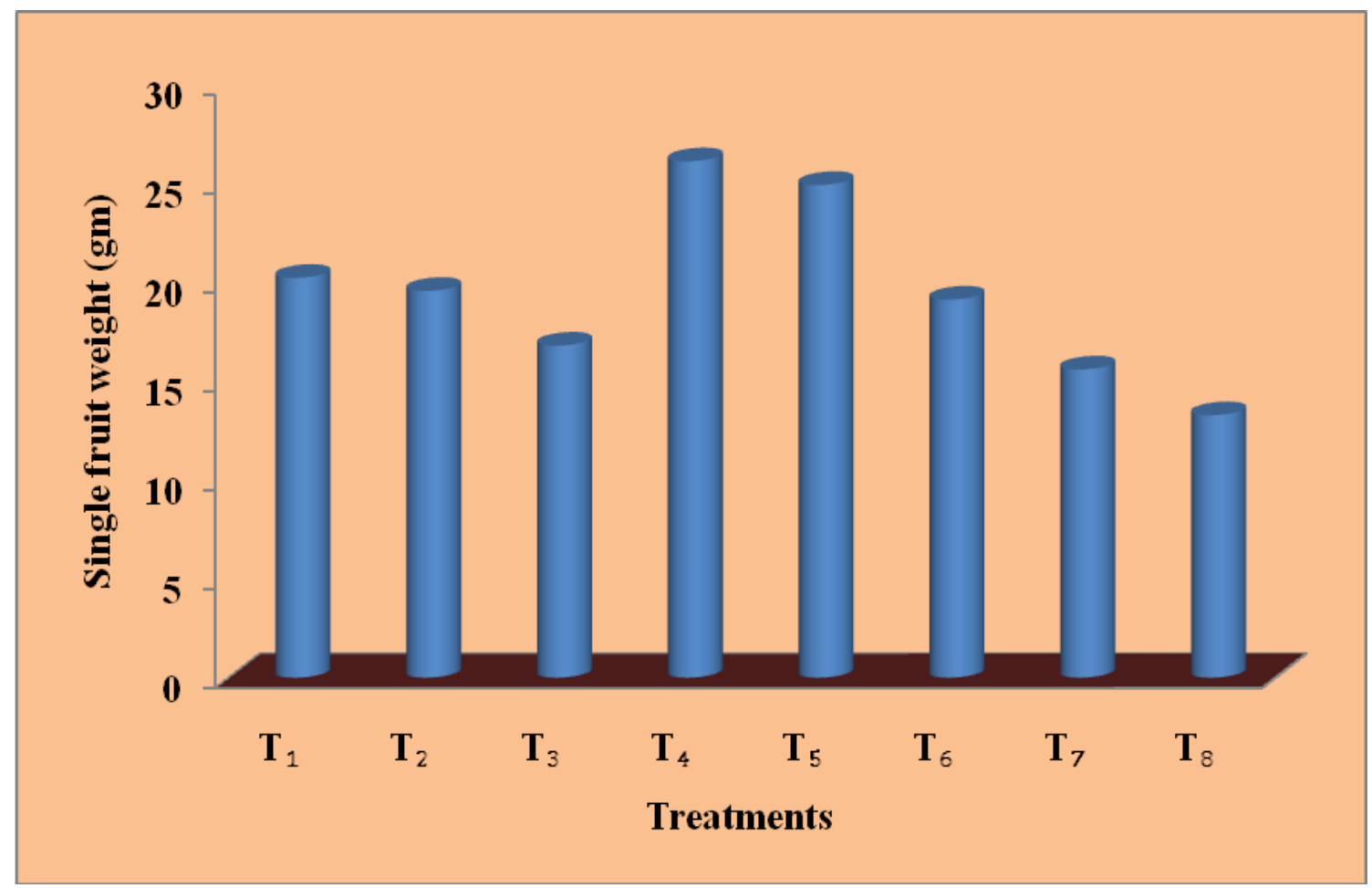


Fig.3 Effect of graded doses of fertigation and mulching on duration of maximum retention of shelf life of pointed gourd

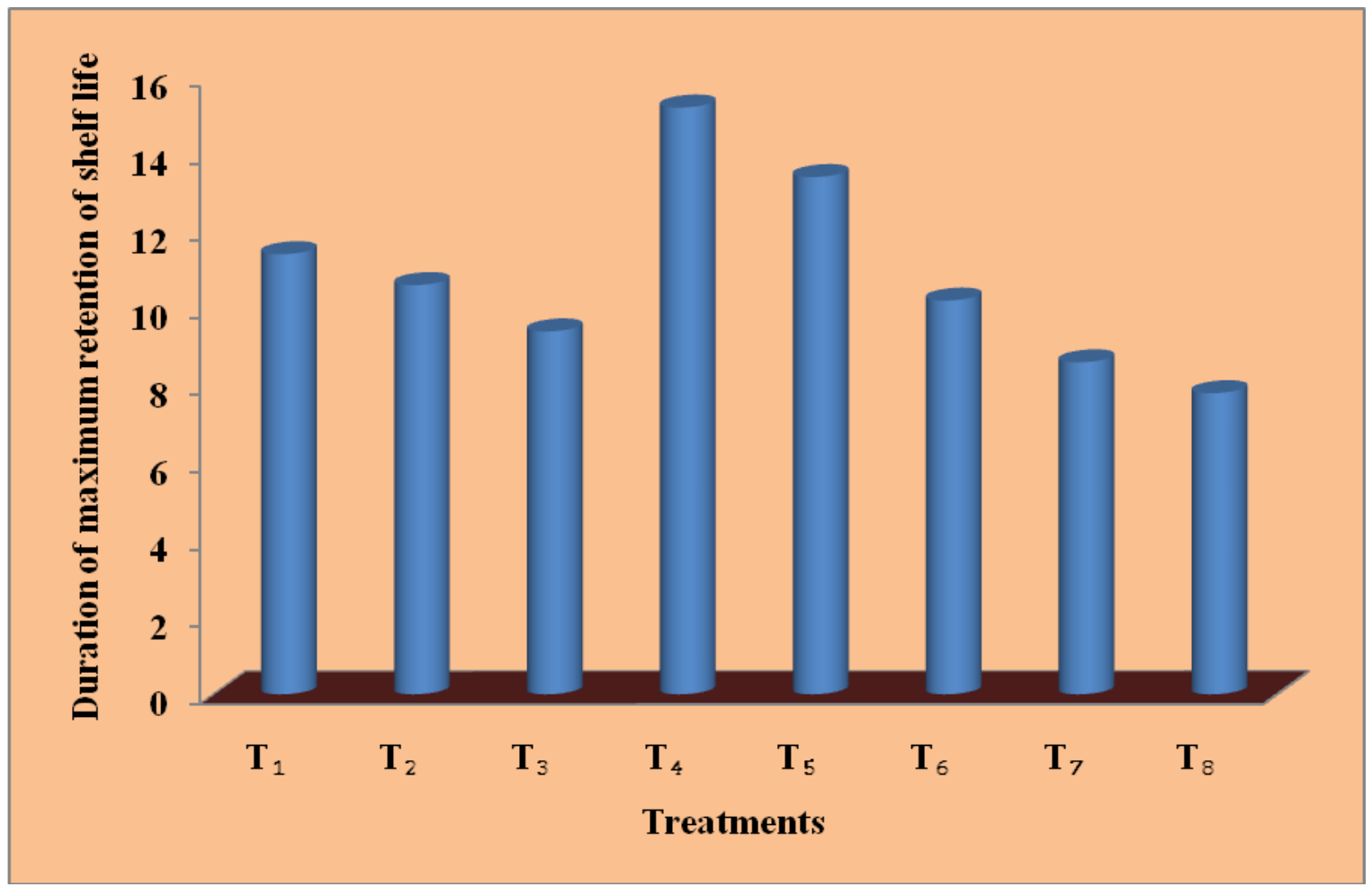

Fig.4 Effect of graded doses of fertigation and mulching on percentage of marketable fruits of pointed gourd

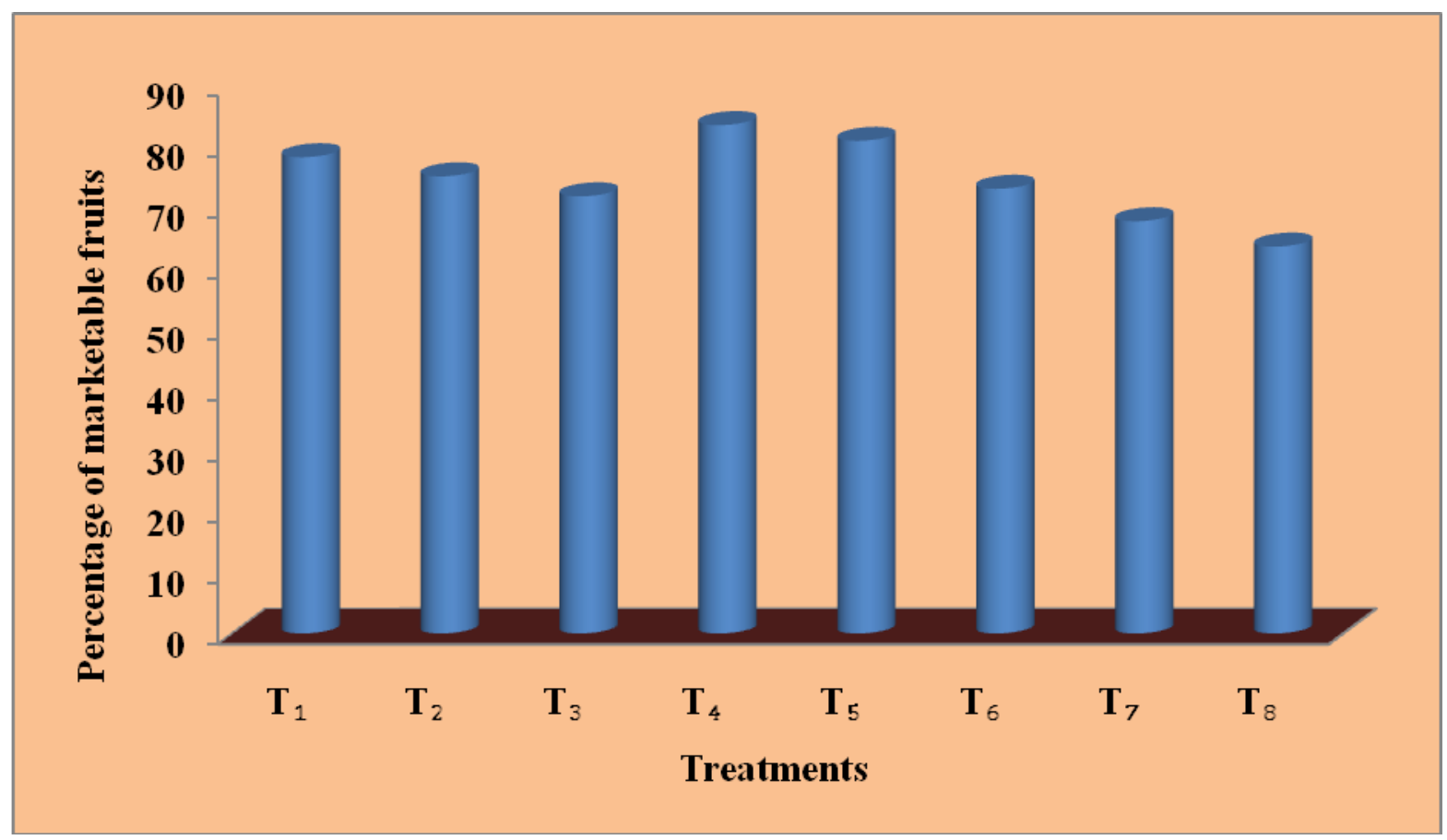


Table.1 Effect of graded doses of fertigation and mulching on number of days to 50\% flowering, length of fruit, girth of fruit, single fruit weight, number of seeds per fruit, duration of maximum retention of shelf life and percentage of marketable fruits of pointed gourd

\begin{tabular}{|c|c|c|c|c|c|c|c|c|}
\hline \multicolumn{2}{|c|}{ Treatment } & \multirow{2}{*}{ 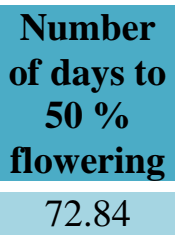 } & \multirow{2}{*}{$\begin{array}{c}\begin{array}{c}\text { Length } \\
\text { of fruit } \\
\text { (cm) }\end{array} \\
7.92\end{array}$} & \multirow{2}{*}{$\begin{array}{l}\begin{array}{c}\text { Girth } \\
\text { of fruit } \\
(\mathrm{cm})\end{array} \\
8.47\end{array}$} & \multirow{2}{*}{$\begin{array}{l}\text { Single } \\
\text { fruit } \\
\text { weight } \\
(\mathrm{g}) \\
20.23\end{array}$} & \multirow{2}{*}{$\begin{array}{c}\begin{array}{c}\text { Number } \\
\text { of seeds/ } \\
\text { fruit }\end{array} \\
13.28\end{array}$} & \multirow{2}{*}{$\begin{array}{c}\begin{array}{c}\text { Duration of } \\
\text { maximum } \\
\text { retention of } \\
\text { shelf life }\end{array} \\
11.4\end{array}$} & \multirow{2}{*}{$\begin{array}{c}\begin{array}{c}\text { Percentage } \\
\text { of } \\
\text { marketable } \\
\text { fruits (\%) }\end{array} \\
\mathbf{7 8 . 2 6} \\
\end{array}$} \\
\hline$T_{1}$ & Fertigation with $100 \%$ RDF & & & & & & & \\
\hline$T_{2}$ & Fertigation with $80 \%$ RDF & 71.33 & 7.58 & 8.17 & 19.57 & 12.33 & 10.6 & 75.12 \\
\hline$T_{3}$ & Fertigation with $60 \%$ RDF & 75.12 & 6.87 & 7.55 & 16.8 & 14.68 & 9.4 & 71.83 \\
\hline $\mathbf{T}_{4}$ & $\begin{array}{l}\text { Fertigation with } 100 \% \text { RDF } \\
+ \text { mulching }\end{array}$ & 66.34 & 9.09 & 9.23 & 26.13 & 11.6 & 15.2 & 83.54 \\
\hline $\mathbf{T}_{5}$ & $\begin{array}{l}\text { Fertigation with } 80 \% \text { RDF + } \\
\text { mulching }\end{array}$ & 67.66 & 8.52 & 8.81 & 24.93 & 14.53 & 13.4 & 80.95 \\
\hline $\mathrm{T}_{6}$ & $\begin{array}{l}\text { Fertigation with } 60 \% \text { RDF }+ \\
\text { mulching }\end{array}$ & 70.68 & 7.19 & 7.8 & 19.13 & 13.4 & 10.2 & 73.07 \\
\hline $\mathrm{T}_{7}$ & $\begin{array}{l}\text { Drip irrigation + RDF in soil } \\
\text { application }\end{array}$ & 76.21 & 6.43 & 7.27 & 15.6 & 13.73 & 8.6 & 67.74 \\
\hline $\mathbf{T}_{8}$ & $\begin{array}{l}\text { Irrigation in furrow without } \\
\text { mulching + RDF in soil } \\
\text { application }\end{array}$ & 83.62 & 5.46 & 6.74 & 13.28 & 12.15 & 7.8 & 63.57 \\
\hline & Mean & 72.97 & 7.38 & 8.00 & 19.45 & 13.21 & 10.8 & 74.26 \\
\hline & $\operatorname{SEm}( \pm)$ & 0.80 & 0.20 & 0.49 & 0.57 & 0.67 & 0.62 & 1.65 \\
\hline & $\mathrm{CD}_{(0.05)}$ & 2.43 & 0.61 & NS & 1.75 & NS & 1.88 & 5.02 \\
\hline & CV & 1.90 & 4.73 & 10.80 & 5.15 & 8.86 & 9.96 & 3.86 \\
\hline
\end{tabular}

Production of nucleoproteins, enzymes and high-energy bonds due to application of phosphorus as well as more auxin production in the presence of higher dose of nitrogen might have resulted in higher fruit weight as reported by Rahul et al., (2010) in cucumber. This result is in general agreement with those reported by Ram et al., (2013) in pointed gourd, Shinde et al., (2010), Gupta et al., (2014), Aniekwe and Anike (2015) and Sikarwar and Hardaha (2016) in cucumber, Meenakshi et al., (2007) and Hari and Devi (2016) in bitter gourd, Alenazi et al., (2015) in muskmelon.

\section{Post-harvest parameters}

Duration of maximum retention of shelf life and highest percentage marketable fruits after a fortnight of storage was recorded in the treatment with 100 percent RDF applied through fertigation and mulching which was significantly superior to other treatments but remained at par with treatment where 80 percent RDF was applied through fertigation and mulching (Fig. 3 and 4). The shelf life has been increased because of the combined effect of optimum utilisation of nutrients and water by the pointed gourd plants through fertigation and mulching in a sustainable manner and thus the shelf life and percentage marketable fruits were increased. The results are in confirmation with Arancibia and Motsenbocker (2008) in watermelon, Rajasree and Pillai (2012) in bitter gourd and Kapoor et al., (2014) and Savita et al., (2017) in cauliflower.

It can be summed up that highest yield, yield attributing characters and post-harvest shelf 
life parameters like number of days taken for $50 \%$ flowering, length of fruit, single fruit weight, duration of maximum retention of shelf life, percentage of marketable fruits etc. of pointed gourd could be achieved by application of $100 \%$ RDF through fertigation and mulching but it remained at par with treatments where $80 \%$ RDF was applied through fertigation and mulching.

\section{Acknowledgement}

The authors are thankful to Principal Investigator Precision Farming Development Centre for the support and encouragement for carrying out the research work at its centre in Orissa University of agriculture and Technology, Bhubaneswar and Department of Vegetable science to attach M.Sc students to carry out the research work.

\section{References}

Alenazi M, Abdel-Razzak H, Ibrahim A, Wahb-Allah M and Alsadon A. (2015) Response of muskmelon cultivars to plastic mulch and irrigation regimes under greenhouse conditions. The Journal of Animal and Plant Sciences; 25(5):1398-1410.

Aniekwe NL and Anike NT. (2015) Effects of different mulching materials and plant densities on the environment, growth and yield of cucumber. IOSR Journal of Agriculture and Veterinary Science; 8(2):64-72.

Arancibia RA and Motsenbocker CE. (2008) Differential watermelon fruit size distribution in response to plastic mulch and spunbonded polyester rowcover. HortTechnology; 18(1):45-52.

Choudhari SM and More TA. (2002) Fertigation, fertilizer and spacing requirement of tropical gynoecious cucmber hybrids. Acta Horticulturae; 588:233-240.
Grubben GJH. (1997) Tropical vegetable and their genetic resources, Royal Tropical Institute, Amsterdam, Netherlands; 453.

Gupta AJ, Chattoo MA and Bhat FN. (2014) Standardization of drip irrigation and fertigation practices for commercial cultivation of hybrid cucumber under Kashmir conditions. Progressive Horticulture; 46(2):343-348.

Hagin J, Sneh M and Lowengart-Aycicegi A. (2002) Fertigation - Fertilization through irrigation, IPI Research Topics No. 23, Ed. by A.E. Johnston, International Potash Institute, Basel, Switzerland; 1-73.

Hari AA and Devi LG. (2016) Studies on fertigation in bitter gourd (Momordica charantia L.). Journal of Crop and Weed; 12(2):91-95.

Kapoor R, Sandal SK, Sharma SK, Kumar A and Saroch K. (2014) Effect of varying drip irrigation levels and NPK fertigation on soil water dynamics, productivity and water use efficiency of cauliflower (Brassica oleracea var. Botrytis) in wet temperate zone of Himachal Pradesh. Indian Journal of Soil Conservation; 42(3):249 -254.

Meenakshi N, Vadivel E and Kavita M. (2007) Response of bitter gourd (Momordica charantia L.) on fruit yield and quality traits as influenced by fertigation levels, The Asian Journal of Horticulture; 2(2):126-130.

Rahul A, Kade and Singh D. (2010) Influence of interaction effect on NPK on number of fruits per vine and weight of fruit in cucumber (Cucumis sativus L.) cv. Japanese long green. Vegetable Science; 37(1):69-71.

Rajasree G and Pillai GR. (2012) Effect of nitrogen nutrition on fruit quality and shelf life of cucurbitaceous vegetable bitter gourd. Journal of plant nutrition; 35(8):1139-1153. 
Ram JP, Dwivedi SV and Anand RK. (2013) Studies on effect of mulching and training on growth, yield and economics of pointed gourd (Trichosanthes dioica Roxb.). The Asian Journal of Horticulture; 8(2):645-647.

Rani R, Nirala SK and Suresh R. (2012) Effect of fertigation and mulch on yield of pointed gourd in calcareous soil of north Bihar. Environment \& Ecology; 30(3A):641-645.

Savita B, Luchon S, Bonti G and Sonbeer C. (2017) Fertigation level and mulching in cauliflower (Brassica oleracea L. var. botrytis) cv. snowball white. International Journal of Agriculture Sciences; 9(21):4226-4228.
Shinde JB, Malunjkar BD, Raut RS, Patil PD and Thawal DW. (2010) Response of cucumber to fertigation under drip irrigation system. BIOINFOLET-A Quarterly Journal of Life Sciences; 7(2):161-164.

Sikarwar P and Hardaha MK. (2016) Effect of fertigation levels on growth, quality and yield of polyhouse cucumber (Cucumis sativus). International Journal of Agriculture Sciences; 8(43):1863-1866.

Sukhatme PV and Amble VN. (1995) Statistical methods for Agricultural workers, ICAR, New Delhi.

Taiz L and Zeiger E. (1991) Mineral nutrition, In: Plant Physiology, The Benjamin Cummings Pub. Co. Inc., New York, USA, 114.

\section{How to cite this article:}

Nayak, H., D. Sahoo, S.C. Swain, B. Jena, D. Paramjita and Bisoyi, B.S. 2018. Influence of Fertigation Doses and Mulching on Yield Attributing Characters and Post-Harvest Shelf Life of Pointed Gourd (Trichosanthes dioica Roxb.). Int.J.Curr.Microbiol.App.Sci. 7(04): 3212-3220. doi: https://doi.org/10.20546/ijcmas.2018.704.364 